\title{
Traducción de The Unfortunate Bride or The Blind Lady, a Beauty de Aphra Behn
}

JUAN JESÚs ZARO

Universidad de Málaga

Fecha de recepción: 17 abril 2007

Fecha de aceptación: 28 junio 2007

INTRODUCCIÓN

La figura de Aphra Behn (1640-1689) se perfila cada vez más como una de las personalidades artísticas más complejas de la Inglaterra de su época. Este relato, The Unfortunate Bride or The Blind Lady, a Beauty, fue publicado después de su muerte, concretamente en 1698. Hay en él retazos de aspectos tratados con más amplitud en otras obras: la alteridad, en este caso maligna, representada por el personaje de Moorea; el poder de la escritura o la ceguera como metáfora de la sexualidad femenina y del papel de la mujer en la relación amorosa. Su lenguaje, por otra parte, refleja el estado, aún balbuceante, de la prosa de ficción inglesa pocos años antes de la irrupción de la novela moderna. Estos rasgos se han intentado respetar en la traducción.

\section{VERSIÓN ORIGINAL EN INGLÉS.}

THE UNFORTUNATE BRIDE: Epistle Dedicatory.

TO RICHARD NORTON, OF SOUTHWICK IN HANTSHIRE, ESQUIRE.

Honour'd Sir,

Eminent wit, Sir, no more than eminent beauty, can escape the trouble and presumption of addresses; and that which can strike every body with wonder, can never avoid the praise which naturally flows from that wonder: and heaven is fore'd to hear the addresses as well as praises of the poor as rich, of the ignorant as learned, and takes, nay rewards, the officious tho perhaps impertinent zeal of its least qualtfy'd devotees. Wherefore, Sir, tho your merits meet with the applause of the learned and witty, yet your generosity will judge favourably of the untaught zeal of an humbler admirer, since what I do your eminent vertues compel. The beautiful will permit the most despicable of their admirers to love them, tho they never intend to make him happy, as unworthy their love, but they will not be angry at the fatal effect of their own eyes.

But what I want in my self, Sir, to merit your regard, I hope my authoress will in some measures supply, so far at least to lessen my 
presumption in prefixing your name to a posthumous piece of hers, whom all the men of wit, that were her contemporaries, look'd on as the wonder of her sex; and in none of her performances has she shew'd so great a mastery as in her novels, where nature always prevails; and if they are not true, they are so like it, that they do the business every jot as well.

This I hope, Sir, will induce you to pardon my presumption in dedicating this novel to you, and declaring my self, Sir,

Your most obedient and most humble servant,

S. Briscoe.

THE UNFORTUNATE BRIDE; or, The Blind Lady a Beauty.

Frankwit and Wildvill, were two young gentlemen of very considerable fortunes, both born in Staffordshire, and, during their minority, both educated together, by which opportunity they contracted a very inviolable friendship, a friendship which grew up with them; and though it was remarkably known to every body else, they knew it not themselves; they never made profession of it in words, but actions; so true a warmth their fires could boast, as needed not the effusion of their breath to make it live. Wildvill was of the richest family, but Frankwit of the noblest;Wildvill was admired for outward qualifications, and strength, and manly proportions, Frankwit for a much softer beauty, for his inward endowments, pleasing in his conversation, of a free, and moving air, humble in his behaviour, and if he had any pride, it was but just enough to shew that he did not affect humility; his mind bowed with a motion as unconstrained as his body, nor did he force this vertue in the least, but he allowed it only. Soaimablehe was, that every virgin that had eyes, knew too she had a heart, and knew as surely she should lose it. His Cupid could nol be reputed blind, he never shot for him, but he was sure to wound. As every other nymph admired him, so he was dear to all the tuneful sisters; the Muses were fired with him as much as their own radiant god Apollo; their loved springs and fountains were not so grateful to their eyes as he, him they esteemed their Helicon and Parnassus too; in short, when ever he pleased, he could enjoy them all. Thus he enamour'd the whole female sex, but amongst all the sighing captives of his eyes, Beivira only boasted charms to move him; her parents lived near his and even from their childhood they felt mutual love, as if their eyes, at their first meeting, had struck out such glances, as had kindled into amorous flame. And now Belvira in her fourteenth year (when the fresh spring of young virginity began to cast more lively bloomings in her cheeks, and softer longings in her eyes), 
by her indulgent father's care was sent to London to a friend, her mother being lately dead: when, as if fortune ordered it so, Frankwit's father took a journey to the other world, to let his son the better enjoy the pleasures and delights of this: the young lover now with all imaginable haste interred his father, nor did he shed so many tears for his loss, as might in the least quench the fire which he received from his llelvira's eyes, but (master of seventeen hundred pounds a year, which his father left him) with all the wings of love flies to London, and sollicits Belvira with such fervency, that it might be thought he meant death's torch should kindle Hymen's; and now as soon as he arrives at his journey's end, he goes to pay a visit to the fair mistress of his soul, and assures her, that tho he was absent from her, yet she was still with him; and that all the road he travell'd, her beauteous image danced before him, and like the ravished Prophet, he saw his deity in every bush; in short, he paid her constant visits, the sun ne'er rose or set, but still he saw it in her company, and every minute of the day he counted by his sighs. So incessantly he importuned her that she could no longer hold out, and was pleased in the surrender of her heart, since it was he was conqueror; and therefore felt a triumph in her yielding. Their flames now joyned, grew more and more, glowed in their cheeks, and lightened in their glances: eager they looked, as if there were pulses beating in their eyes; and all endearing, at last she vowed, that Frankwit living she would ne'er be any other man's. Thus they past on some time, while every day rowl'd over fair; heaven showed an aspect all serene, and the sun seemed to smile at what was done. He still caressed his charmer, with an innocence becoming his sincerity; he lived upon her tender breath, and basked in the bright lustre of her eyes, with pride, and secret joy.

He saw his rivals languish for that bliss, those charms, those raptures and extatick transports, which he engrossed alone. But now some eighteen months (some ages in a lover's kalendar) winged with delights, and fair Belvira now grown fit for riper joys, knows hardly how she can deny her pressing lover, and herself, to crown their vows, and joyn their hands as well as hearts. All this while the young gallant wash'd himself clean of that shining dirt, his gold; he fancied little of heaven dwelt in his yellow angels, but let them fly away, as it were on their own golden wings; he only valued the smiling babies in Belvira's eyes. His generosity was boundless, as his love, for no man ever truly loved, that was not generous. He thought his estate, like his passion, was a sort of a Pontick Ocean, it could never know an ebb; but now he found it could be fathom'd, and that the tide was turning, therefore he sollicits with more impatience the consummation of their joys, that both might go like martyrs from their flames immediately to heaven; and now at last it was agreed between them, that they should both be one, but not without some reluctancy on the female side; for 'tis the humour of our 
sex, to deny most eagerly those grants to lovers, for which most tenderly we sigh, so contradictory are we to our selves, as if the deity had made us with a seeming reluctancy to his own designs; placing as much discords in our minds, as there is harmony in our faces. We are a sort of aiery clouds, whose lightning flash out one way, and the thunder another. Our words and thoughts can ne'er agree. So this young charming lady thought her desires could live in their own longings, like misers' wealth-devouring eyes; and e'er she consented to her lover, prepared him first with speaking looks, and then with a fore-running sigh, applyed to the dear charmer thus: 'Frankwit, I am afraid to venture the matrimonial bondage, it may make you think your self too much confined, in being only free to one.' 'Ah! my dear Belvira,' he replied, 'thai one, like Manna, has the taste of all, why should I be displeased to be confined to paradice, when it was the cur.se of our forefathers to be set at large, tho they had the whole world to roam in: you have, my love, ubiqukary charms, and you are all in all, in every part.' 'Ay, but,' reply'd Belvira, 'we are all like perfumes, and too continual smelling makes us seem to have lost our sweets, I'll be judged by my cousin Celesia here, if it be not better to live still in mutual love, without the last enjoyment.' (I had forgot to tell my reader that Celesia was an heiress, the only child of a rich turkey merchant, who, when he dyed, left her fifty thousand pound in money, and some estate in land; but, poor creature, she was blind to all these riches, having been born without the use of sight, though in all other respects charming to a wonder.) 'Indeed,' says Celesia (for she saw clearly in her mind), 'I admire you should ask my judgment in such a case, where I have never had the least experience; but I believe it is but a sickly soul which cannot nourish its offspring of desires without preying upon the body.' 'Believe me,' reply'd Frankwit, 'I bewail your want of sight, and I could almost wish you my own eyes for a moment, to view your charming cousin, where you would see such beauties as are too dazling to be long beheld; and if too daringly you gazed, you would feel the misfortune of the loss of sight, much greater than the want of it: and you would acknowledge, that in too presumptuously seeing, you would be blinder then, than now unhappily you are.'

'Ah! I must confess,' reply'd Belvira, 'my poor, dear cousin is blind, for I fancy she bears too great an esteem for Frankwit, and only longs for sight to look on him.' 'Indeed,' reply'd Celesia, 'I would be glad to see Frankwit, for I fancy he's as dazling, as he but now describ'd his mistress, and if I fancy I see him, sure I do see him, for sight is fancy, is it not? or do you feel my cousin with your eyes?' 'This is indeed, a charming blindness,' reply'd Frankwit, 'and the fancy of your sight excels the certainty of ours. Strange! that there should be such glances even in blindness? You, fair maid, require not eyes to conquer, if your night has such stars, what 
sunshine would your day of sight have, if ever you should see?' 'I fear those stars you talk of,' said Belvira, 'have some influence on you, and by the compass you sail by now, I guess you are steering to my cousin. She is indeed charming enough to have been another offspring of bright Venus, blind like her brother Cupid.' 'That Cupid,' reply'd Celesia, 'I am afraid has shot me, for methinks I would not have you marry Frankwit, but rather live as you do without the last enjoyment, for methinks if he were marry'd, he would be more out of sight than he already is.' 'Ah, Madam,' return'd Frankwit, 'love is no camelion, it cannot feed on air alone.' 'No but,' rejoyn'd Celesia, 'you lovers that are not blind like love it self, have am'rous looks to feed on.' 'Ah! believe it,' said Belvira, tis better, Frankwit, not to lose paradice by too much knowledge; marriage enjoyments does but wake you from your sweet golden dreams: pleasure is but a dream, dear Frankwit, but a dream, and to be waken'd.' 'Ah! dearest, but unkind Belvira,' answer'd Frankwit, 'sure there's no waking from delight, in being lull'd on those soft breasts of thine.' 'Alas! (reply'd the bride to be) it is that very lulling wakes you; women enjoy'd, are like romances read, or raree-shows, once seen, meer tricks of the slight of hand, which, when found out, you only wonder at your selves for wondering so before at them. 'Tis expectation endears the blessing; heaven would not be heaven, could we tell what 'tis. When the plot's out you have done with the play, and when the last act's done, you see the curtain drawn with great indifferency.' 'O my Belvira,' answered Frankwit, 'that expectation were indeed a monster which enjoyment could not satisfy: I should take no pleasure,' he rejoin'd, 'running from hill to hill, like children chasing that sun, which I could never catch.' 'O thou shalt have it then, that sun of love,' reply'd Belvira, fir'd by this complaint, and gently rush'd into arms, (rejoyn'd) so Phœbus rushes radiant and unsullied, into a gilded cloud. 'Well then, my dear Belvira,' answered Frankwit, 'be assured I shall be ever yours, as you are mine; fear not you shall never draw bills of love upon me so fast, as I shall wait in readiness to pay them; but now I talk of bills, I must retire into Cambridgeshire, where I have a small concern as yet unmortgaged, I will return thence with a brace of thousand pounds within a week at furthest, with which our nuptials, by their celebration, shall be worthy of our love. And then, my life, my soul, we shall be join'd, never to part again.' This tender expression mov'd Belvira to shed some few tears, and poor Celesia thought herself most unhappy that she had not eyes to weep with too; but if she had, such was the greatness of her grief, that sure she would have soon grown blind with weeping. In short, after a great many soft vows, and promises of an inviolable faith, they parted with a pompous sort of pleasing woe; their concern was of such a mixture of joy and sadness, as the weather seems, when it both rains and shines. And now the last, the very last adieu's was over, for the farewels of lovers hardly ever end, and Frankwit (the time being 
summer) reach'd Cambridge that night, about nine a clock (strange! that he should have made such haste to fly from what so much he lov'd!); and now, tir'd with the fatigue of his journey, he thought fit to refresh himself by writing some few lines to his belov'd Belvira; for a little verse after the dull prose company of his servant, was as great an ease to him (from whom it flow'd as naturally and unartifically, as his love or his breath), as a pace or handgallop, after a hard, uncouth, and rugged trot. He therefore, finding his Pegasus was no way tir'd with his land-travel, takes a short journey thro the air, and writes as follows:

My dearest dear Belvira,

You knew my soul, you knew it yours before,

I told it all, and now can tell no more;

Your presents never wants fresh charms to move,

But now more strange, and unknown pow'r you

prove,

For now your very absence 'tis

I love. Something there is which strikes my wandring view,

And still before my eyes I fancy you.

Charming you seem, all charming, heavenly fair,

Bright as a goddess, does my love appear,

You seem, Belvira, what indeed you are.

Like the angelick off-spring of the skies,

With beatifick glories in your eyes:

Sparkling with radiant lustre all divine,

Angels, and Gods! oh heavens! how bright they shine!

Are you Belvira? can I think you mine!

Beyond ev'n thought, I do thy beauties see,

Can such a heaven of heavens be kept for me!

Oh be assur'd, I shall be ever true,

I must

For if I would, I can't be false to you.

Oh! how I wish I might no longer stay,

Tho I resolve 1 will no time delay,

One tedious week, and then l'll fleet away.

Tho love be blind, he shall conduct my road,

Wing'd with almighty love, to your abode,

I'll fly, and grow immortal as a god.

Short is my stay, yet my impatience strong,

Short tho it is, alas! I think it long.

I'll come, my life, new blessings to persue, 
Love then shall fly a flight he never flew,

I'll stretch his balmy wings; I'm yours,-AAdieu.

Frankwit.

This letter Belvira receiv'd with unspeakable joy, and laid it up safely in her bosom; laid it, where the dear author of it lay before, and wonderfully pleas'd with his humour of writing verse, resolv'd not to be at all behindhand with him, and so writ as follows:

My dear Charmer,

You knew before what power your love could boast,

But now your constant faith confirms me most.

Absent sincerity the best assures,

Love may do much, but faith much more allures,

For now your constancy has bound me yours.

I find, methinks, in verse some pleasure too,

I cannot want a Muse, who write to you

Ah! soon return, return, my charming dear,

Heav'n knows how much we mourn your absence here:

My poor Celesia now would charm your sou,

Her eyes, once blind, do now divinely rowl.

An aged matron has by charms unknown,

Given her clear sight as perfect as thy own.

And yet, beyond her eyes, she values thee,

'Tis for thy sake alone she's glad to see.

She begg'd me, pray remember her to you,

That is a task which now I gladly do.

Gladly, since so I only recommend

A dear relation, and a dearer friend,

Ne're shall my love —but here my note must end.

Your ever true Belvira.

When this letter was written, it was strait shown to Celesia, who look'd upon any thing that belong'd to Frankwit, with rejoycing glances; so eagerly she perus'd it, that her tender eyes beginning to water, she cry'd out, (fancying she saw the words dance before her view) 'Ah! Cousin, cousin, your letter is running away, sure it can't go itself to Frankwit.' A great deal of other pleasing innocent things she said, but still her eyes flow'd more bright with lustrous beams, as if they were to shine out; now all that glancing 
radiancy which had been so long kept secret, and, as if, as soon as the cloud of blindness once was broke, nothing but Lightnings were to flash for ever after. Thus in mutual discourse they spent their hours, while Frankwit was now ravished with the receipt of this charming answer of Belvira's, and blest his own eyes which discovered to him the much welcome news of fair Celesia's. Often he read the letters o're and o're, but there his fate lay hid, for 'twas that very fondness proved his ruin. He lodg'd at a cousin's house of his, and there (it being a private family), lodged likewise a blackamoor Lady, then a widower; a whimsical Knight had taken a fancy to enjoy her: Enjoy her did I say? Enjoy the devil in the flesh at once! I know not how it was, but he would fain have been a bed with her, but she not consenting on unlawful terms (but sure all terms are with her unlawful), the Knight soon marry'd her, as if there were not hell enough in matrimony, but he must wed the devil too. The Knight a little after died, and left this Lady of his (whom I shall name Moorea) an estate of six thousand pounds per ann. Now this Moorea observed the joyous Frankwit with an eager look, her eyes seemed like stars of the first magnitude glaring in the night; she greatly importuned him to discover the occasion of his transport, but he denying it, (as 'tis the humour of our sex), made her the more inquisitive; and being jealous that it was from a mistress, employ'd her maid to steal it, and if she found it such, to bring it her: accordingly it succeeded, for Frankwit having drank hard with some of the gentlemen of that shire, found himself indisposed, and soon went to bed, having put the letter in his pocket: the maid therefore to Moorea contrived that all the other servants should be out of the way, that she might plausibly officiate in the warming the bed of the indisposed lover, but likely, had it not been so, she had warmed it by his intreaties in a more natural manner; he being in bed in an inner room, she slips out the letter from his pocket, carries it to her mistress to read, and so restores it whence she had it; in the morning the poor lover wakened in a violent fever, burning with a fire more hot than that of love. In short, he continued sick a considerable while, all which time the Lady Moorea constantly visited him, and he as unwillingly saw her (poor gentleman) as he would have seen a parson; for as the latter would have perswaded, so the former scared him to repentance. In the mean while, during his sickness, several letters were sent to him by his dear Belvira, and Celesia too (then learning to write), had made a shift to give him a line or two in postscript with her cousin, but all was intercepted by the jealousy of the black Moorea, black in her mind, and dark, as well as in her body. Frankwit too writ several letters as he was able, complaining of her unkindness, those likewise were all stopt by the same blackamoor devil. At last, it happened that Wildvill (who I told my reader was Frankwit's friend), came to London, his father likewise dead, and now master of a very 
plentiful fortune, he resolves to marry, and paying a visit to Belvira, enquires of her concerning Frankwit, she all in mourning for the loss, told him his friend was dead. 'Ah! Wildvill, he is dead,' said she, 'and died not mine, a blackamoor Lady had bewitched him from me; I received a letter lately which informed me all; there was no name subscribed to it, but it intimated, that it was written at the request of dying Frankwit.' 'Oh! I am sorry at my soul,' said Wildvill, 'for I loved him with the best, the dearest friendship; no doubt then,' rejoyned he, "tis witchcraft indeed that could make him false to you; what delight could he take in a blackamoor Lady, tho she had received him at once with a soul as open as her longing arms, and with her petticoat put off her modesty. Gods! How could he change a whole field argent into downright sables.' "Twas done,' returned Celesia, 'with no small blot, I fancy, to the female 'scutcheon.' In short, after some more discourse, but very sorrowful, Wildvill takes his leave, extreamly taken with the fair Belvira, more beauteous in her cloud of woe; he paid her afterwards frequent visits, and found her wonder for the odd inconstancy of Frankwit, greater than her sorrow, since he dy'd so unworthy of her. Wildvill attack'd her with all the force of vigorous love, and she (as she thought) fully convinc'd of Frankwit's death, urg'd by the fury and impatience of her new ardent lover, soon surrender'd, and the day of their nuptials now arriv'd, their hands werejoyn'd. In the mean time Frankwit (for he still liv'd) knew nothing of the injury the base Moorea practis'd, knew not that 'twas thro her private order, that the fore-mention'd account of his falshood and his death was sent; but impatient to see his dear Belvira, tho yet extremely weak, rid post to London, and that very day arriv'd there, immediately after the nuptials of his mistress and his friend were celebrated. I was at this time in Cambridge, and having some small acquaintance with this blackamoor Lady, and sitting in her room that evening, after Frankwit's departure thence, in Moorea's absence, saw inadvertently a bundle of papers, which she had gathered up, as I suppose, to burn, since now they grew but useless, she having no farther hopes of him: I fancy'd I knew the hand, and thence my curiosity only led me to see the name, and finding Belvira subscrib'd, I began to guess there was some foul play in hand. Belvira being my particularly intimate acquaintance, I read one of them, and finding the contents, convey'd them all secretly out with me, as I thought, in point of justice I was bound, and sent them to Belvira by that night's post; so that they came to her hands soon after the minute of her marriage, with an account how, and by what means I came to light on them. No doubt but they exceedingly surpriz'd her: but Oh! much more she grew amaz'd immediately after, to see the poor, and now unhappy Frankwit, who privately had enquir'd for her below, being received as a stranger, who said he had some urgent 
business with her, in a back chamber below stairs. What tongue, what pen can express the mournful sorrow of this scene! At first they both stood dumb, and almost senseless; she look him for the ghost of Frankwit; he looked so pale, new risen from his sickness, he (for he had heard at his entrance in the house, that his Belvira marry'd Wildvill) stood in amaze, and like a ghost indeed, wanted the power to speak, till spoken to the $A$ first. At last, he draws his sword, designing there to fall upon it in her presence; she then imagining it his ghost too sure, and come to kill her, shrieks out and swoons; he ran immediately to her, and catch'd her in his arms, and while he strove to revive and bring her to herself, tho that he thought could never now be done, since she was marry'd. Wildvill missing his bride, and hearing the loud shriek, came running down, and entring the room, sees his bride lie clasp'd in Frankwit's arms. 'Ha! traytor!' He cries out, drawing his sword with an impatient fury, 'have you kept that strumpet all this while, curst Frankwit, and now think fit to put your damn'd cast mistress upon me: could not you forbear her neither ev'n on my wedding day? abominable wretch!' thus saying, he made a full pass at Frankwit, and run him thro' the left arm, and quite thro the body of the poor Belvira; that thrust immediately made her start, tho' Frankwit's endeavours all before were useless. Strange! that her death reviv'd her! For ah! she felt, that now she only liv'd to die! Striving thro wild amazement to run from such a scene of horror, as her apprehensions shew'd her; down she dropt, and Frankwit seeing her fall (all friendship disannull'd by such a chain of injuries), draws, fights with, and stabs his own lov'd Wildvill. Ah! Who can express the horror and distraction of this fatal misunderstanding! The house was alarm'd, and in came poor Celesia, running in confusion just as Frankwit was offring to kill himself, to die with a false friend, and perjur'd mistress, for he suppos'd them such. Poor Celesia now bemoan'd her unhappiness of sight, and wish'd she again were blind. Wildvill dy'd immediately, and llelvira only surviv'd him long enough to unfold all their most unhappy fate, desiring Frankwit with her dying breath, if ever he lov'd her (and now she said that she deserv'd his love, since she had convinced him that she was not false), to marry her poor dear Celesia, and love her tenderly for her Belvira's sake; leaving her, being her nearest relation, all her fortune, and he, much dearer than it all, to be added to her own; so joyning his and Celesia's hands, she poured her last breath upon his lips, and said, 'Dear Frankwit, Frankwit, I die yours.' With tears and wondrous sorrow he promis'd to obey her will, and in some months after her interrment, he perform'd his promise. 


\section{TRADUCCIÓN AL ESPAÑOL.}

La esposa desafortunada: dedicatoria epistolar Al caballero Richard Norton, de Southwick in Hantshire.

Honorable señor:

Señor, la belleza y el ingenio eminentes no pueden escapar de la molestia y la osadía de las adulaciones. Lo que despierta la admiración de todo el mundo difícilmente puede evitar el elogio que naturalmente fluye de ella: así, el cielo se ve obligado a oír las adulaciones y elogios de los pobres y de los ricos, de los ignorantes y de los instruidos y recibe, no los premios, sino el entusiasmo constante, aunque quizá impertinente, de sus devotos menos cualificados. Por eso, señor, aunque vuestros méritos reciban el aplauso de los instruidos y de los ingeniosos, vuestra generosidad, no obstante, sabrá juzgar favorablemente la adhesión natural de un humilde admirador, pues lo que hago viene inducido por vuestras eminentes virtudes. Aunque los hermosos se dejen querer por el más despreciable de sus admiradores, si bien nunca intenten hacerlo feliz por ser indigno del amor de ellos, éste no se enojará por el efecto fatal de sus propios ojos.

Señor, espero que mi autora sepa proporcionaros en alguna medida lo que a mí me falta para ser digno de vuestra consideración, lo bastante al menos para aliviar mi atrevimiento al prefijar nuestro nombre a una de sus piezas póstumas. Considerada como una de las maravillas de su sexo, en ninguna de sus producciones ha demostrado tanta maestría como en sus novelas. Pues, si no son verdad, son tan semejantes a ella que parecen serlo letra a letra.

Espero que esto, señor, os induzca a perdonar mi osadía al dedicaros esta novela. Me declaro, señor, vuestro servidor más humilde y obediente,

S. Briscoe.

\section{La esposa desafortunada, o la hermosa dama ciega.}

Frankwit y Wildwill eran dos caballeros jóvenes de fortuna muy considerable, nacidos ambos en Staffordshire. De niños se habían educado juntos, por cuyo motivo habían contraído una inquebrantable amistad que creció con los dos y que era evidente para todo el mundo, menos para ellos. Nunca hacían profesión de ella con palabras, sino con acciones, y el calor de sus fuegos era tan cierto que no necesitaban soplar para mantenerlo vivo. La familia de Wildwill era la más rica, y la de Frankwit la más noble; mientras que Wildwill era admirado por sus atributos exteriores, su fuerza y 
su constitución varonil, Frankwit lo era por una belleza mucho más sutil, por los atributos de su espíritu, por su agradable conversación, de carácter libre y conmovedora, por ser humilde en su conducta y porque, si mostraba alguna arrogancia, era justo la precisa para demostrar que no fingía humildad. Su mente era tan ágil y flexible como su cuerpo, una cualidad que no forzaba en absoluto sino que simplemente dejaba fluir. Era tan simpático que toda virgen con ojos se daba perfecta cuenta de que tenía corazón y de que, con la misma seguridad, iba a perderlo. Su Cupido nunca habría tenido la fama de ser ciego: aunque nunca disparaba por él, sus flechas habrían herido sin duda alguna. Igual que una de cada dos ninfas lo admiraba, gustaba a todas las melódicas hermanas. Las musas se encendían con él tanto como con su radiante dios Apolo; sus amadas fuentes y riachuelos no les eran tan queridos a sus ojos como él, que era también su Helicón y su Parnaso. En pocas palabras, siempre que quería podía disfrutar de todas. Sin embargo, aunque lograra enamorar a todo el sexo femenino, de entre todas las cautivas que suspiraban ante sus ojos sólo Belvira podía alardear de poseer encantos para conmoverle. Sus padres vivían cerca de los suyos, y desde sus infancias había sentido un amor mutuo, como si sus ojos, en su primer encuentro, se hubieran intercambiado miradas encendidas que prendieran una llama de amor. Belvira, que ahora tenía catorce años (la edad en que la fresca corriente de la lozana virginidad empezaba a aflorar con colores más vivos en sus mejillas y anhelos más sutiles en sus ojos), había sido enviada por el celo indulgente de su padre a Londres para vivir con un amigo, tras la reciente muerte de su madre. Entonces, como por un dictamen de la fortuna, el padre de Frankwit emprendió viaje al otro mundo, para permitir a su hijo disfrutar mejor de los placeres y delicias de éste. El joven enamorado, con toda la prisa imaginable, enterró a su padre sin verter demasiadas lágrimas por su pérdida, pues podrían haber apagado el fuego que había recibido de los ojos de su Belvira. Por el contrario, al disponer de setecientas libras al año, que su padre le había dejado, vuela hasta Londres con todas las alas del amor y corteja a Belvira con tal fervor que parece como querer que la antorcha de la muerte encienda la de Himeneo. Así, en cuanto llega a su destino, corre a visitar a la hermosa dueña de su alma y le asegura que, a pesar de haber estado apartados uno del otro, ella siempre había estado con él; que, durante todo el camino, su bella imagen había danzado ante sus ojos y que, igual que el asombrado profeta, él había visto a su deidad en cada zarza. En pocas palabras, iba a visitarla frecuentemente; ya se pusiera o saliera, el sol siempre la veía con ella, cuyos suspiros, además, le servían para contar los minutos. Tan insistente fue el acoso que ella no pudo resistirse. Él se felicitó cuando ella le entregó su corazón, pues al ser él quien lo había conquistado consideró su cesión como un triunfo. Una vez unidas, sus respectivas llamas no hicieron más 
que crecer, brillar en sus mejillas y encenderse en sus miradas. Parecían ansiosos, como si sus ojos latieran, y tan amorosos que ella terminó jurando que, mientras Frankwit viviera, nunca pertenecería a otro hombre. Así pasaron algún tiempo, en el que cada día fue bueno; el cielo mostraba un aspecto completamente sereno y el sol parecía sonreír ante lo que se había hecho. Él seguía acariciando a su enamorada con una inocencia que traslucía su propia sinceridad. Se alimentaba de su suave aliento y se miraba en el lustre brillante de sus ojos con orgullo y secreta alegría.

Veía a sus rivales languidecer por aquella dicha, aquellos encantos, aquellos éxtasis y arrobamientos de los que sólo él disfrutaba. Sin embargo, transcurridos unos dieciocho meses (que son varias eras en el calendario de un enamorado) repletos de delicias, a la bella Belvira, dispuesta ya a experimentar placeres más maduros, le empezó a resultar difícil negar a su insistente amante, y a ella misma, la coronación de sus votos y la unión de sus manos, además de la de sus corazones. Todo esto sucedía mientras el joven galán se quedaba prácticamente sin aquel polvo brillante, su oro; pues al imaginar que en sus ángeles amarillos moraba muy poca sustancia celestial, los dejó volar lejos con sus propias alas doradas: lo único que valoraba eran los infantes sonrientes que veía en los ojos de Belvira. Su generosidad había sido ilimitada, igual que su amor, pues no existe ningún hombre que haya amado de verdad y que no sea generoso. Había creído que sus propiedades, como su pasión, eran una especie de mar Póntico sin fondo, pero ahora comenzaba a descubrir que éste podía ser sondeado y que la marea estaba cambiando.

Por eso ruega con más impaciencia la consumación de sus placeres para que así ambos puedan pasar, como mártires, de las llamas al cielo. Y así, por fin, quedó acordado entre ellos que ambos serían uno solo, pero no sin cierta reticencia por parte del lado femenino; pues es característica de nuestro sexo negar con gran vehemencia estos premios a nuestros amantes, precisamente a aquellos por los que más tiernamente suspiramos. Así de contradictorias somos con nosotras mismas, como si la realidad nos hubiera dotado de una aparente reticencia a sus propios designios, colocando tanta discordancia en nuestras mentes como armonía en nuestros rostros. Somos como nubes ligeras, cuyos relámpagos brillan por un lado y los truenos por otro. Nuestras palabras y pensamientos nunca se ponen de acuerdo. Así, esta dama joven y encantadora creía que sus deseos podían vivir en sus propios anhelos, igual que ojos de tacaños que devoran riquezas contemplándolas. Por eso, antes de consentir a los deseos de su amante, lo preparó primero con miradas elocuentes y luego, tras un revelador suspiro, le dijo así: 
-Frankwit, tengo miedo de que nos sometamos al vínculo matrimonial. Puede hacer que te sientas prisionero disponer sólo de una mujer.

-Mi hermosa Belvira —respondió él—, si esa mujer, como el maná, concentra los sabores de todas, ¿por qué me iba a desagradar ser prisionero del paraíso, cuando precisamente disponer de un sitio tan grande fue la maldición de nuestros primeros padres, aunque tuvieran todo el mundo para vagar por él?

-Sí — respondió Belvira-, pero somos como perfumes y un olor demasiado continuo podría hacernos creer que hemos perdido nuestros aromas. Voy a consultar a mi prima Celesia si no sería mejor seguir amándonos mutuamente, sin llegar al último placer (Había olvidado decir a mi lector que Celesia era una heredera, hija única de un rico comerciante de Turquía que, al morir, le había dejado cincuenta mil libras y algunas propiedades. Sin embargo, la pobre criatura no podía ver ninguna de estas riquezas, al haber nacido ciega, aunque en todos los demás aspectos fuera encantadora hasta el extremo).

- Celebro que me pidáis consejo para una situación como ésta respondió Celesia, que pensaba con claridad-sobre la que no tengo la menor experiencia, pero creo que sólo un alma enferma podría satisfacer su manantial de deseos sin alimentarse del cuerpo.

- Creedme - respondió Frankwrit-, lamento que no podáis ver y por un momento casi os daría mis propios ojos para que viérais a vuestra encantadora prima, en quien veríais una belleza tan deslumbrante que no podría contemplarse por mucho tiempo; y si os atreviérais a seguir mirando, experimentaríais la desgracia de perder la vista, que es mucho peor que nunca haber visto, y tendríais que admitir que, al haber contemplado con tanto atrevimiento, estábais más ciega de lo que, por desgracia, estáis ahora.

— ¡Ah! Debo lamentar —replicó Belvira- que mi pobre y querida prima esté ciega, porque creo que profesa una estima demasiado grande a Frankwrit y sólo anhela tener vista para contemplarlo.

-En efecto - respondió Celestia-, me alegraría poder ver a Frankwrit porque me lo imagino tan apuesto como lo describe su amada, y si imagino que lo veo, es seguro que lo veo, porque ver es imaginar. ¿O no? ¿O es que sentís con vuestros ojos, prima mía?

- La vuestra es, efectivamente, una ceguera maravillosa -replicó Frankwrit-, y la imaginación de vuestra vista excede ciertamente la certeza de la nuestra. ¡Qué extraño que puedan lanzarse miradas así incluso siendo ciega! A vos, hermosa dama, no os hacen falta ojos para conquistar pues, si vuestra noche está iluminada por tales estrellas... ¿cómo tendría que ser el sol que os ilumine el día para ver, si alguna vez podéis hacerlo? 
-Temo que esas estrellas de las que habláis — dijo Belvira- ejercen alguna influencia sobre vos, y por la brújula con que navegáis ahora, adivino que el rumbo que tomáis os dirige a mi prima. Ella posee, en efecto, encantos suficientes para ser la descendiente de la brillante Venus, ciega como su hermano Cupido.

-Ese Cupido -contestó Celestia-, me temo, me ha alcanzado con sus dardos pues creo que no me gustaría que os casárais con Frankwrit, sino que siguiérais como estáis ahora, sin llegar al último placer; creo que, si él se casara, yo lo vería incluso menos que ahora.

-Ah, señora -intervino Frankwrit—, el amor no es un camaleón y no puede alimentarse sólo del aire.

-No - replicó Celesia-, pero los amantes que, como vosotros, no estáis ciegos como el amor, disponéis de miradas amorosas con las que alimentaros.

—Creedme —dijo Belvira- que es mejor, Frankwrit, no perder el paraíso por querer saber demasiado; lo que hacen los placeres del matrimonio es despertaros de vuestros dulces y dorados sueños: el placer no es sino un sueño, querido Frankwrit, un sueño del que un día se despierta.

-Mi querida, pero cruel, Belvira —contestó Frankwrit-, seguro que no es posible despertar del placer cuando me arrullas en tus suaves pechos.

- Por desgracia —contestó la futura esposa-, ese mismo arrullo es el que te despierta: las mujeres disfrutadas son como novelas leídas o teatros de marionetas que, una vez los habéis visto, descubrís que son simplemente trucos de la mano y os asombráis de que os maravillaran tanto. Es la espera la que hace adorable la bendición: el cielo no sería el cielo si pudiéramos decir lo que es. Cuando el argumento termina, termina la representación, y cuando termina el último acto, véis bajar el telón con gran indiferencia.

-No, Belvira mía — respondió Frankwrit-, la espera es como un monstruo al que el placer no puede satisfacer. No me complacería continuó- correr de monte a monte, como un niño, persiguiendo un sol que nunca alcanzaré.

-Entonces tendrás ese sol de amor —dijo Belvira, conmovida por sus lamentos, mientras cariñosamente se refugia en brazos de su enamorado, igual que Febo se apresura a ocultarse, radiante e inmaculado, tras una nube dorada.

- Sabed, mi amada Belvira, que siempre seré vuestro, como vos sois mía; no temáis extenderme todas las facturas de amor que queráis, pues estoy ansioso por pagarlas. Pero, hablando de facturas, debo viajar a Cambridgeshire, donde tengo una pequeña propiedad aún no hipotecada, 
de donde regresaré con mil libras dentro de una semana, como muy tarde. Con ellas, la celebración de nuestras nupcias será digna de nuestro amor. Y luego, mi vida, mi alma, estaremos unidos y nunca más nos separaremos.

Esta tierna declaración logró que Belvira derramase algunas lágrimas, y la pobre Celesia se creyó la persona más desgraciada del mundo por no tener tampoco ojos para llorar; si los hubiera tenido, la enormidad de su dolor habría sido tal que entonces seguramente se habría vuelto ciega de tanto llorar. En pocas palabras, tras muchos dulces votos y promesas de fe inviolable, se despidieron con una pomposa mezcla de dolor y complacencia; sus pensares compuestos de dolor y alegría como ese tiempo en que llueve y hace sol a la vez. Y después de que el último adiós hubiera concluido, pues las despedidas de los enamorados no terminan nunca, Frankwrit (era por entonces verano), llegó a Cambridge aquella noche, sobre las nueve (iqué extraño que se apresurara tanto a alejarse de quien tanto amaba!). Cansado por la dureza del viaje, pensó en reponerse escribiendo unos versos a su querida Belvira, pues algo de poesía tras la aburrida compañía en prosa de su criado, era un alivio tan grande para él (de quien brotaba de manera tan natural y poco artificial como su amor o su aliento), como ir al paso o al trote tras un galope duro e incómodo. Así que, tras comprobar que su Pegaso no está de ninguna manera rendido por el viaje, emprende un breve viaje por al aire y escribe lo siguiente:

Mi queridísima querida Belvira:

Conocías mi alma y sabías que era tuya antes

de que yo te lo dijera, y ahora no puedo decir nada.

Tus dones no necesitan nuevos encantos para conmover, pero ahora me descubres un poder más extraño y desconocido, pues en este momento lo que amo es tu ausencia.

Hay algo que sorprende mi errabunda visión, aunque aún, ante mis ojos, te imagino.

Pareces encantadora, toda tú, gloriosamente hermosa, brillante como una princesa aparece mi amor:

sabes, Belvira, lo que de verdad eres.

Como la descendencia angelical del cielo, con glorias beatíficas en los ojos:

Resplandeciente, con brillo radiante todo divino, ¡Ángeles, dioses, cielos! ¡Cómo brillan! ¿Eres Belvira? ¿Puedo creer que eres mía?

Antes siquiera de pensarlo, contemplo tu belleza, ¿Es que la gloria de las glorias puede ser para mi? No te quepa duda, siempre te seré sincero, Debo... 
Pues incluso queriendo, no podría serte falso,

¡Oh, cómo deseo dejar este lugar!

Aunque he decidido que no perderé el tiempo:

una larga semana, y luego me iré.

Aunque el amor sea ciego, me mostrará el camino.

Alado con amor poderoso, hasta tu morada

volaré y seré inmortal como un dios.

Corta será mi estancia, pero fuerte mi impaciencia,

y aunque sea breve, me parecerá larga.

Volveré, vida mía, a pedirte más bendiciones,

y entonces Amor volará un vuelo que nunca ha volado.

Extenderé sus suaves alas. Soy tuyo. Adiós.

Frankwrit.

Belvira recibió esta misiva con indescriptible alegría y la guardó cuidadosamente en su pecho; exactamente en el mismo lugar donde su amado autor había yacido antes. Tan complacida estaba con su decisión de escribir versos que decidió no ser menos que él y escribió lo siguiente:

Mi amado seductor:

Tú ya sabías el poder que podía tener tu amor, pero ahora tu fe inquebrantable me lo confirma.

La sinceridad del ausente es la mejor prueba,

pues el amor hace mucho, pero la fe fascina mucho más.

Pues tu constancia me ha hecho tuya,

creo encontrar en los versos también cierto placer,

y no necesito una musa para escribirte.

¡Regresa pronto, regresa, amado seductor!

El cielo sabe cuánto lamentamos vuestra ausencia:

mi pobre Celesia ahora os alegraría el alma,

pues sus ojos, una vez ciegos, ahora ven perfectamente.

Una anciana matrona, por medio de hechizos desconocidos,

le ha devuelto la vista, que ahora es tan perfecta como la vuestra.

$Y$ sin embargo, por encima de sus ojos, ella os estima

y sólo por ti se alegra de poder ver.

Me ha suplicado que os dé recuerdos,

tarea que ahora hago con alegría.

Con alegría, porque con ello os estoy recomendando

a una pariente querida, una amiga amada,

y nunca mi amor... pero aquí debe acabar mi nota. 
Cuando terminó de escribir esta carta, se la mostró a Celestia, que contemplaba cualquier cosa que perteneciera a Frankwrit con ojos jubilosos. La leyó con tanta intensidad que sus ojos dulces comenzaron a llorar y gritó (al pensar que veía como las palabras danzaban ante ella) lo siguiente:

- ¡Prima, prima, tu carta se va delante de mis ojos! ¿Seguro que no irá hasta Frankwrit?

Dijo también muchas otras cosas tiernas e inocentes, mas de sus ojos seguían brotando rayos brillantes como si fuera a desaparecer. Ahora salía todo ese brillo de miradas que durante tanto tiempo había sido secreto y era como si, una vez que la nube de ceguera hubiese sido rota, sólo pudieran brillar rayos desde entonces. Así pasaron las horas hablándose la una a la otra, mientras Frankwrit, que ya estaba jubiloso al recibir la encantadora respuesta de Belvira, bendijo a sus propios ojos por descubrirle las mucho más ansias noticias de la bella Celestia. Leyó las cartas una y otra vez pero en ellas estaba escondido su destino, pues en su afición se encontraba su ruina Se alojaba en casa de un primo suyo y allí (al ser la casa de una familia sola) se alojaba también una dama de piel oscura que entonces estaba viuda: un caballero caprichoso se había encandilado de ella y la había gozado. ¿Gozado he dicho? ¡Había gozado del propio demonio en carne humana! No sé muy bien lo que pasó, pero lo cierto es que cuando él quiso yacer con ella, la dama no consintió hacerlo de manera ilegal (aunque en realidad todas las maneras con ella eran ilegales), de modo que el caballero enseguida se desposó con ella. $Y$ como si el matrimonio de por sí ya no fuera un infierno, es que encima se había casado con el diablo. El caballero murió poco después y dejó a su dama (a quien a partir de aquí llamaré Moorea) un legado de seis mil libras al año. Ahora, esta Moorea miraba al alegre Frankwrit con deseo. Sus ojos parecían estrellas de grandes dimsensiones que brillaban en la noche. No paró de importunarle para descubrir el motivo de su contento, pero él, que no lo reveló, le acrecentó aún más la curiosidad (como sucede normalmente a nuestro sexo), y despertándole los celos la posibilidad de que se tratara de una mujer, dio instrucciones a su criada para que se enterara y, si lo descubría, se lo dijera a ella. Y así sucedió, pues Frankwrit, tras beber mucho con algunos caballeros de aquel condado, se encontró enfermo y decidió irse a la cama, tras colocar la carta en su bolsillo. La criada de Moorea se las arregló para deshacerse de los demás sirvientes y ser ella quien calentara la cama del amante enfermo. $\mathrm{Y}$, en realidad, de no haber podido usar sus artimañas, lo habría hecho de una manera más natural. Al yacer él en la cama de una habitación interior, ella le saca la carta del bolsillo, se la lleva a su señora para que la lea y luego la devuelve al lugar del que había salido. A la mañana siguiente, el pobre enamorado se 
despertó con fiebre muy alta, quemándose con un fuego mucho más caliente que el del amor. En pocas palabras, estuvo enfermo durante un tiempo considerable, tiempo que Lady Moorea aprovechó para visitarlo constantemente, si bien él la veía con tan pocas ganas (ipobre galán!), como a un sacerdote, pues, igual que el segundo podría haberlo persuadido al arrepentimiento, la primera lo condujo al mismo lugar mediante el miedo. Mientras tanto, durante su enfermedad, le llegaron varias cartas de su querida Belvira, en las que también Celesia (que estaba aprendiendo a escribir) le escribía una línea o dos a modo de postdata. Todas fueron interceptadas por la negra Moorea, cuya mente era negra y oscura igual que su cuerpo. Frankwrit le escribió también varias cartas en cuanto pudo hacerlo, en las que se quejaba de su ingratitud, las cuales fueron también secuestradas por el negro diablo. Por fin, Wildvill (que como dije antes a mi lector era el amigo de Frankwrit), llegó a Londres, al haber muerto también su padre y heredar una considerable fortuna. Viene decidido a casarse y, al hacerle una visita a Belvira, pregunta por Frankwrit. Ella, vestida toda de luto por la pérdida, le dice que su amigo ha muerto.

- ¡Ay, Wildwill, ha muerto - dice- y ha muerto sin ser mío, pues una oscura dama lo hechizó para alejarlo de mi! He recibido una carta en la que se me cuenta todo, y aunque nadie la firmaba, parecía haber sido escrita a petición de Frankwrit, que agonizaba.

-Oh, cuánto lo siento -dijo Wildwill- pues era mi amigo mejor y más querido. Sin duda esa hechicería es lo que ha hecho que te engañara pues, ¿qué placer podía obtener de una dama de piel negra, aunque ella lo recibiera con un alma tan abierta como sus brazos anhelantes y con las enaguas quitadas sin ningún recato? ¡Dios mío! ¿Cómo ha cambiado un fondo de plata por puro negro?

- Imagino que se hizo -contestó Celesia- sin causar la más mínima mancha al honor femenino.

En pocas palabras, tras seguir conversando un poco más, y muy apenado, Wildwill se disculpa, extremadamente atraído por la hermosa Belvira, más bella si cabe en su nube de dolor. A partir de entonces, comenzó a hacerle visitas con frecuencia y descubrió que su asombro por la inconstancia de Frankwrit era más grande que su dolor, pues él había muerto sin ser digno de ella. Wildwill la atacó con todo el poder del amor vigoroso, y ella (tal como pensaba), convencida por completo de la muerte de Frankwrit y urgida por la furia e impaciencia de su nuevo y ardoroso enamorado, cedió enseguida, y una vez anunciada su boda, unieron sus manos. Mientras tanto, Frankwrit (que aún vivía), desconocía la gran herida que le había inflingido Moorea, y seguía sin saber que ella era la causante de las noticias de su traición y muerte. Impacientes por ver a su querida Belvira, pero todavía extremadamente débil, embarca en una diligencia 
hacia Londres y ese mismo día llega allí, inmediatamente antes de que se celebre la boda de su enamorada y su amigo. Yo estaba por aquel entonces en Cambridge, y conocía superficialmente a la dama oscura. Por eso, sentada en sus habitaciones aquella tarde, después de que Frankwrit hubiera partido, y sin que Moorea estuviera presente, me fijé sin quererlo en un montón de papeles que ella habia reunido, supongo que para quemarlos, puesto que ya eran inútiles al haber cesado ella de tener esperanzas en él. La letra me resultaba conocida, y por ello mi curiosidad me llevo a fijarme en el nombre, y al ver la firma de Belvira, empecé a pensar que algún plan malévolo había sido urdido. Como Belvira era mi amiga más íntima, leí una de las cartas y al conocer el contenido las saqué de la estancia sin que nadie se percatase, pues pensé que se lo debía en justicia a Belvira, a quien se las envié por el correo nocturno. Llegaron a sus manos minutos después de haber contraído matrimonio, con una nota que explicaba cómo y por qué las había encontrado. Sin duda, le causaron gran asombro, pero mucha mayor sorpresa le causó inmediatamente después ver al pobre, y ahora infortunado, Frankwrit, que tras preguntar por ella y ser recibido como un extraño, había dicho que tenía que hablarle urgentemente y la esperaba en una habitación trasera. ¡Qué lengua, qué pluma podría expresar el lúgubre tono de esta escena! Al principio, los dos se miraron atontados y casi sin sentido. Ella pensó que se trataba del fantasma de Frankwrit pues él, pálido y recién recuperado de su enfermedad, se quedó inmóvil y sorprendido (pues al entrar en la casa había oído que su amada Belvira se había desposado con Wildwill) y parecía en efecto un fantasma, incapaz de articular palabra hasta que alguien se la dirigiera. Por fin, él saca su espada con la intención de matarse allí mismo en presencia de ella. Belvira, que imagina que se trata en efecto de un fantasma que viene a matarla, lanza un grito y se desvanece. Él corre enseguida hacia ella y la coge en sus brazos, mientras intenta revivirla y recuperarla, aunque piense que es imposible lograrlo tras haberse casado ella. Wildwill, echando de menos a su esposa, y tras oír el agudo grito, llega corriendo y, al entrar en la estancia, ve a su esposa en brazos de Frankwrit.

- iTraidor! - grita, sacando la espada con furia impaciente- ¿Has estado con esa puta todo este tiempo, maldito Frankwrit, y ahora te parece bien quitarme a la enamorada que tú mismo habías abandonado? ¿Es que no podías contenerte ni siquiera el día de mi boda? ¡Abominable desgraciado!

Y, diciendo esto, clavó la espada en el brazo izquierdo de Frankwrit, atravesándolo y entrando en el cuerpo de la pobre Belvira. La estocada la hizo reaccionar, a pesar de que los esfuerzos anteriores de Frankwrit habían sido inútiles. ¡Qué extraño que su muerte la hiciera revivir! ¡Pues ahora sintió que sólo viviría para morir! Esforzándose, en medio de su 
asombro, por escapar de aquella escena de horror que sus temores le mostraban, cayó al suelo y Frankwrit, al verla caer, (toda la amistad deshecha después de tal carnicería), saca su espada, pelea y la clava en su querido Wildwill. ¡Ah! ¿Quién podría expresar el horror y la locura de este fatal malentendido? Por aquel entonces, toda la casa ha oído gritos y entra la pobre Celesia, corriendo confundida justo cuando Frankwrit está a punto de matarse, para morir con un amigo falso y una enamorada que ha cometido perjurio, pues así era cómo veía a los dos. La pobre Celesia lamenta ahora la triste escena que ve y desea volver a estar ciega. Wildwill murió enseguida y Belvira sólo le sobrevivió lo suficiente para saber las razones de su infeliz destino, pidiendo a Frankwrit con su aliento agonizante que, si alguna vez la había amado (ahora ella decía que merecía su amor, al haberlo convencido de que no lo había engañado), desposara a la pobre y querida Celesia y la amara tiernamente en su recuerdo. A ella, al ser su pariente más próxima, le dejaba toda su fortuna y a él, posesión mucho más querida, para que se acumulara a la suya propia. Así que, uniendo las manos de Frankwrit y de Celesia, exhaló su último aliento y dijo:

-Querido Frankwrit, muero siendo tuya.

Entre lágrimas, y en medio de un inmenso dolor, él prometió obedecer sus deseos y pocos meses después de su entierro cumplió su promesa. 
